\title{
Doclang, Makanan Tradisional Yang Mulai Tersisihkan
}

\author{
Nurul Sukma Lestari ${ }^{1)}$, Christina ${ }^{2)}$ \\ Hotel Management Department, Faculty of Economic and Communication \\ Bina Nusantara University, Jakarta, Indonesia 11480 \\ E-mail: nurul.lestari@binus.edu'
}

\begin{abstract}
Doclang is a typical traditional Bogor food found in Indonesia. The composition contained in doclang, are: lontong or pesor in Sundanese, fried tofu, boiled eggs and fried steamed potatoes and bean spices as an aditional. The uniqueness found in doclang is from rice cake made using patat leaves and cooked for a long time. This study aims to obtain an overview of the existence of Doclang in the Bogor community. This research was conducted using qualitative methods by directly collecting data by conducting observations and interviews. The results of the study show that there are two versions of the origin of Doclang, namely the influence of the Chinese community and artisans of diamonds. In making Doclang, Pesor and potatoes are used as a differentiator from kupat tahu. And at this time in the city of Bogor has provided a place for culinary tourism such as Doclang, which is on Jalan Jembatan Merah or Jalan Veteran which is sold by street vendors.
\end{abstract}

\section{Keywords: Doclang, Lontong, Patat leaves, Preserving}

Abstrak - Doclang merupakan makanan tradisional Khas Bogor yang terdapat di Indonesia. Komposisi yang terdapat pada doclang yaitu: lontong atau pesor dalam Bahasa Sunda, tahu goreng, telor rebus dan kentang kukus yang digoreng serta bumbu kacang sebagai pelengkap. Keunikan yang terdapat pada doclang adalah dari lontong yang dibuat menggunakan daun patat dan dimasak dalam waktu yang lama. Penelitian ini bertujuan untuk memperoleh gambaran tentang keberadaan Doclang di masyarakat Bogor khususnya. Penelitian ini dilakukan menggunakan metode kualitatif dengan langsung mengumpulkan data dengan melakukan observasi dan wawancara. Hasil penelitian menunjukan bahwa terdapat dua versi asal usul Doclang, yaitu pengaruh dari masyarakat Tionghoa dan pengrajin ketupat. Dalam pembuatan Doclang dipergunakan Pesor dan kentang sebagai pembeda dari kupat tahu. Serta pada saat ini di Kota Bogor sudah menyediakan tempat untuk wisata kuliner seperti Doclang, yaitu di Jalan Jembatan Merah atau Jalan Veteran yang dijual oleh para pedagang kaki lima.

Kata Kunci: Doclang, Lontong, Daun Patat, Pelestarian

\subsection{Latar Belakang}

Indonesia merupakan salah satu negara dengan banyak kepulauan dan berbagai suku bangsa yang hidup di dalamnya. Terdiri dari 34 provinsi, dimana setiap daerah memiliki masakan yang merupakan ciri khas dari masingmasing daerah. Dilihat dari letak geografisnya yang strategis, Indonesia sangatlah menguntungkan karena menjadi penghasil dari berbagai macam sumber makanan dan masakan traditional. Banyak yang mendapatkan pengaruh dari berbagai negara asing sejak dahulu kala, karena banyak bangsa asing yang datang baik untuk berdagang ataupun menetap di Indonesia. Kuliner merupakan hasil dari budaya dan berkaitan erat dengan masyarakat (Nitisuari \& Wardono, 2014). Makanan tradisional adalah makanan termasuk minuman dan jajanan dan bahan-bahan yang digunakan secara tradisional (Nurhalimah, 2016). Seiring dengan berkembangnya jaman, generasi muda saat ini lebih memilih makanan cepat saji dibandingkan dengan jajanan tradisional (Arifin, 2017). Kaum muda menganggap bahwa makanan tradisional kurang berkelas dan gengsi untuk menyantapnya (Adiasih \& Brahmana, 2015), ini mengakibatkan makanan tradisional semakin terabaikan keberadaannya dan bukan tidak mungkin akan hilang ditelan jaman. Masyarakat perkotaan sekarang ini banyak yang berpikir bahwa jika menyantap makanan tradisional mereka tidak mengikuti perkembangan jaman, karena anggapan bahwa makanan tradisional tidak berkelas dan tidak mempunyai nilai komersial dibandingkan dengan makanan cepat saji (Setyawati \& Rimawati, 2016). Sehingga saat ini makanan tradisional sudah sangat jarang ditemukan seiring dengan adanya perubahan zaman (Rahmalianti \& Riyadi, 2016). Karenanya diperlukan upaya untuk melestarikan dan mengembangkan makanan tradisional (Oda, 2012).

Bogor merupakan salah satu daerah di Indonesia yang memiliki beragam masakan tradisional, termasuk di dalamnya adalah jajanan tradisional. Salah satu makanan/jajanan tradisional Bogor yang mulai hilang adalah 'Doclang'. Doclang berupa potongan ketupat dan tahu yang disiram bumbu kacang, dimana makanan ini biasa disantap pada saat makan pagi/sarapan (Ahmadlbo, t.thn.). Pada jaman 
dahulu doclang ini diperdagangkan dengan cara dipikul dan hanya berjualan mulai pukul 05.30 sampai 07.30 (Setiawan, 2015). Sekarang ini Doclang hanya dijual di beberapa titik di daerah Bogor.

Dengan latar belakang pembahasan di atas, ada tiga permasalahan yang dapat peneliti kaji dalam upaya pelestarian makanan tradisional dari Bogor ini, yaitu: (1) Bagaimana asal usul makanan Doclang sebagai salah satu makanan khas Kota Bogor? (2) Apa keunikan yang dimiliki oleh makanan Doclang khas Bogor? (3) Bagaimana cara melestarikan makanan tradisional Doclang khas Kota Bogor?

\subsection{Kajian Pustaka \\ 2.1.1. Bogor}

Kota Bogor dilihat dari letak georafisnya terletak di $106.48^{\circ}$ Bujur Timur dan $6.36^{\circ}$ Lintang Utara. Luas Kota Bogor adalah 111, 73 km2 dengan 949,066 populasi penduduk (BPS, 2010). Kota Bogor dapat dikatakan sebagai pintu gerbang dari provinsi Jawa Barat, karena berjarak $60 \mathrm{~km}$ dari Jakarta sebagai lbu Kota Negara Republik Indonesia dan $120 \mathrm{~km}$ ke Bandung sebagai Ibu Kota Provinsi Jawa Barat, sangatlah berpotensi untuk dikunjungi oleh wisatawan baik dalam negeri maupun mancanegara (Afriyani, 2011). Karena keberadaannya yang dekat dengan Ibukota, maka kota Bogor menjadi salah satu destinasi pariwisata unggulan secara nasional (Mulyana, 2012). Pengembangan pariwisata di kota Bogor diarahkan pada kegiatan wisata kuliner, belanja, budaya, Iptek, rekreasi dan hiburan, berdasarkan Rencana Pembangunan Jangka Panjang (RPJP) Kota Bogor 2005-2025 (Gunawan, 2016). Salah satu kecamatan di Bogor memiliki potensi wisata yang sangat beragam dan berpotensi untuk dikembangkan (Tosida et al., 2015).

\subsubsection{Kuliner Sunda}

Makanan kuliner Sunda merupakan makanan tradisional yang terkenal di Indonesia karena keunikannya, yaitu kesegaran dari bahan yang digunakan terutama sayur-sayuran mentah yang segar (Fajri, 2018). Makanan Sunda merupakan makanan yang biasa dikonsumsi oleh masyarakat Sunda, dan menggunakan bahan yang ada di daerah tersebut serta memliki rasa yang sesuai dengan selera orang Sunda (Yasminia, 2003). Saat ini kuliner Sunda dijadikan salah satu komoditas dalam perekonomian masyarakat (Hartanti et al., 2012). Kuliner Sunda menampilkan cita rasa yang ringan dan sederhana tetapi memiliki rasa yang gurih asin, asam segar, manis ringan, dan segar (Gardjito et al., 2018).

\subsubsection{Doclang}

Menurut Kepala Dinas Kebudayaan dan Pariwisata Kota Bogor, Shahlan Rasyidi, kota
Bogor memang terkenal akan kulinernya yang khas, diantaranya ada: toge goreng, laksa, soto kuning, doclang, roti unyil, dan lapis talas sangkuriang (Khatimah, 2018). Doclang adalah makanan tradisional yang berasal dari Bogor, biasanya disantap pada pagi hari. Doclang terdiri dari irisan lontong yang dibungkus daun Patat, irisan kentang rebus, tahu goreng, kerupuk dan telur rebus. Dimana pada saat penyajian disiram dengan bumbu kacang yang sedikit pedas dan beraroma rempah dan bisa ditambahkan kecap jika diinginkan (nasional.kompas.com, 2010).

Doclang mirip dengan kupat tahu, hanya saja terdapat perbedaan pada saus kacangnya yang kasar dan lontong/pesor dalam bahasa daerah setempat yang dibungkus dengan menggunakan daun Patat. Keuntungan dari penggunaan daun patat adalah aroma yang khas dan kandungan protein dan serat yang tinggi (Simantjuntak, 2015). Hal lain yang membedakan Doclang dengan kupat tahu dan ketoprak adalah penggunaan kentang rebus (Ahmadlbo, t.thn.). Salah satu bahan pelengkap yang benar-benar khas adalah penggunaan kecap asli buatan Bogor, yakni kecap cap Zebra (Afn \& Dbs, 2014). Salah satu lokasi penjualan Doclang adalah di Jalan Mantarena Lebak, Bogor ataupun di Jembatan Merah (Hoerudin, 2013).

\subsubsection{Lontong/Pesor}

Lontong adalah salah satu masakan rumahan yang terbuat dari beras yang dibungkus dengan menggunakan daun pisang, daun kelapa ataupun plastik (Amelia et al., 2014). Pesor adalah sejenis ketupat yang terbuat dari beras putih dan dibungkus dengan menggunakan daun Patat yang banyak tumbuh di kaki Gunung Salak (Tredoria.com, 2017).

\subsubsection{Daun Patat}

Daun patat merupakan pembungkus alami yang sudah sejak lama digunakan sebagai pembungkus makanan (Badar, 2006). Daun patat termasuk dalam kelompok tanaman Maranta arundinaceae L dan genus Phrynium (Wawo \& Sukamto, 2011). Daun patat masih banyak tumbuh liar di kaki gunung Salak (Yulianti, 2015). Phrynium ditemukan juga di daerah Bogor, tumbuhan ini menyerupai tumbuhan arrowroot dan oleh orang Sunda diberi nama patat daun dengan tinggi 1,5-2,2 meter (Badar, 2006).

\subsection{Metode Penelitian}

Metode yang digunakan dalam penelitian ini adalah metode kualitatif. Metode kualitatif adalah penelitian yang mendeskripsikan dan menganalisis fenomena, peristiwa, sosial, sikap, kepercayaan, persepsi, pemikiran orang maupun kelompok (Hamdi \& Bahruddin, 2014). Sedangkan menurut Prof.Dr.Soegiyono kualitatif 
adalah metode penelitian yang berlandaskan pada postpositivisme (sering disebut paradigma yang memandang realitas sosial sebagai sesuatu yang utuh, kompleks dan penuh makna (Soegiyono, 2017). Untuk analisa hasil yang diperoleh, peneliti menggunakan analisis deskriptif kualitatif yaitu dengan memberikan ulasan atau interpretasi terhadap data yang diperoleh sehingga menjadi lebih jelas dan bermakna dengan sekedar angka-angka (Soegiyono, 2017).

\subsubsection{Lokasi Penelitian}

Lokasi penelitian Doclang berlokasi di Kota Bogor tepatnya di Jalan Jembatan Merah yang merupakan lokasi kuliner makanan Kota Bogor, yang ada Doclang Umi Icoh dan Doclang 405 Aos. Jalan Pasir Kuda No. 23 Kota Bogor ini merupakan salah satu tempat Doclang yang terkanal yaitu Doclang Pak Odik.

\subsubsection{Teknik Pengumpulan Data}

Teknik pengumpulan data yang digunakan adalah:

1. Observasi adalah proses keterlibatan peneliti dalam situasi sosial, kemudian peneliti mengungkapkan seluruh apa yang dilihat, dialami, dan dirasakan langsung oleh peneliti (Soegiyono, 2017).

2. Wawancara merupakan pertemuan dua orang untuk bertukar informasi dan ide melalui tanya jawab, sehingga dapat dikonstruksikan makna dalam suatu topik tertentu (Soegiyono, 2017).

3. Dokumentasi adalah salah satu metode pengumpulan data kualitatif dengan melihat atau menganalisis dokumen-dokumen yang dibuat oleh subjek sendiri atau oleh orang lain tentang subjek (Soegiyono, 2017).

4. Kuesioner merupakan teknik pengumpulan data yang dilakukan dengan cara memberi seperangkat pertanyaan atau pernyataan tertulis kepada responden untuk dijawabnya (Soegiyono, 2017).

5. Sudi pustaka, berkaitan dengan kajian teoritis dan referensi lain yang terkait dengan nilai, budaya, dan norma yang berkembang pada situasi sosial yang diteliti (Soegiyono, 2017).

\subsubsection{Teknik Analisis Data}

Teknik analisa data dalam penelitian ini ialah menggunakan teknik dari Miles dan Huberman yang terdiri dari 3 komponen yaitu :1) Reduksi data, 2) Penyajian data dan 3) Penarikan kesimpulan dan verifikasi (Soegiyono, 2017).

\subsubsection{Gastronomy}

Dalam pengetian antar bangsa kuliner, gastronomi adalah 'The Art of Good Cooking' atau suatu pengetahuan dan ketrampilan tentang seni memasak yang baik, sedangkan dalam pengertian bahasa antar bangsa gastronomi adalah 'The Art of Good Eating' atau dalam kata lain adalah suatu pengetahuan dan ketrampilan tentang seni makan yang baik (Ketaren, 2017). Gastronomi adalah sebuah ilmu yang mempelajari hubungan antara makanan dan seni budaya, dimana ilmu ini menjadi satu kesatuan proses yang dimulai dari mencari sejarah, memilih bahan baku, persiapan sebelum memasak, proses memasak, penyajian dengan tidak melupakan kandungan gizi (Maengkom, 2015).

\subsection{Hasil Dan Pembahasan Penelitian \\ 4.1.1. Profil Narasumber}

Penelitian mengenai Doclang ini dilakukan dengan observasi dan wawancara secara mendalam kepada lima Narasumber. Narasumber yang didapatkan berdasarkan pencarian di internet mengenai tempat-tempat penjualan Doclang dan juga dari web tripadvisor.com, responden yang berasal dari Dinas Kebudayaan dan Pariwisata Kota Bogor, dan Dinas Koperasi UMKM Kota Bogor. Berikut adalah tabel yang berisi profil Narasumber:

\section{Tabel 1: Profil Narasumber}

\begin{tabular}{|l|l|l|l|}
\hline No & \multicolumn{1}{|c|}{$\begin{array}{c}\text { Nama Nara } \\
\text { Sumber }\end{array}$} & \multicolumn{1}{|c|}{ Wilayah } & \multicolumn{1}{|c|}{$\begin{array}{c}\text { Keteranga } \\
\text { n }\end{array}$} \\
\hline 1 & $\begin{array}{l}\text { Doclang Umi } \\
\text { Icoh - Ibu Ima }\end{array}$ & $\begin{array}{l}\text { Jalan Perintis } \\
\text { Kemerdekaan } \\
\text { Jembatan } \\
\text { Merah } \\
\text { Veteran }\end{array}$ & $\begin{array}{l}\text { Pembuat } \\
\text { dan } \\
\text { pedagang }\end{array}$ \\
\hline 2 & $\begin{array}{l}\text { Doclang 405 } \\
\text { Aos - Bpk } \\
\text { Rahman }\end{array}$ & $\begin{array}{l}\text { Jalan Kapten } \\
\text { Muslihat } \\
\text { No.22, } \\
\text { Cibogor }\end{array}$ & $\begin{array}{l}\text { Pembuat } \\
\text { dan } \\
\text { pedagang }\end{array}$ \\
\hline 3 & $\begin{array}{l}\text { Doclang Pak } \\
\text { Odik - Bpk } \\
\text { Ismail }\end{array}$ & $\begin{array}{l}\text { Jalan Pasir } \\
\text { Kuda No. 23, } \\
\text { Pasir Kuda }\end{array}$ & $\begin{array}{l}\text { Pembuat } \\
\text { dan } \\
\text { pedagang }\end{array}$ \\
\hline 4 & $\begin{array}{l}\text { Dinas } \\
\text { Kebudayaan } \\
\text { dan Pariwisata } \\
\text { Kota Bogor - } \\
\text { lbu Yuni }\end{array}$ & $\begin{array}{l}\text { Jalan Pandu } \\
\text { Raya No. 45, } \\
\text { Tegal Gundil, } \\
\text { Bogor Tengah }\end{array}$ & $\begin{array}{l}\text { Pembina } \\
\text { Kabid Keb }\end{array}$ \\
\hline 5 & $\begin{array}{l}\text { Dinas Koperasi } \\
\text { UMKM Bogor- } \\
\text { bpk. Uci }\end{array}$ & $\begin{array}{l}\text { Jalan Dadali } \\
\text { No.2 No.3, } \\
\text { Tanah Sareal }\end{array}$ & $\begin{array}{l}\text { Ketua } \\
\text { Dinas } \\
\text { Koperasi } \\
\text { UMKM }\end{array}$ \\
\hline \multicolumn{3}{|l|}{} \\
\hline
\end{tabular}

\subsubsection{Sejarah Asal Mula Doclang}

Terdapat dua versi cerita mengenai sejarah asal mula doclang yang mulai berada di kota Bogor. Versi yang pertama menurut Dinas Kebudayaan dan Pariwisata Kota Bogor Ibu Yeni menceritakan bahwa awal mula doclang berasal dari Negara China atau Tionghoa yang keberadaannya sudah ada di Indoneia membawa makanan tradisional asal negaranya yaitu berupa nasi dengan adanya daging didalamnya, yang dibungkus atau dibalut oleh nasi yang menggunakan pembungkus daun bamboo. Proses memasak yang membutuhkan waktu lama dengan manfaat agar makanan tersebut tahan lama. Masuknya bacang ke 
Negara Indonesia membuat masyarakat Indonesia ini menyesuaikan dengan keadaan lingkungan masyarakat Indonesia sendiri, khususnya indra perasa masyarakat sendiri. Modifikasi yang disesuaikan dengan masyarakat sekitar adalah mengganti daun bambu dengan daun patat, dimana aromanya sudah familiar dan keberadaannya yang mudah untuk didapat di daerah sekitar. Selain itu mengganti daging dengan bahan lain yaitu bumbu kacang tanah yang dibuat menjadi halus atau kasar lalu disiram di atas nasi tersebut. Masuknya ke masyarakat sunda, nasi yang dimasak dalam waktu lama seperti bacang ini memiliki sebutan khusus bagi orang sunda sendiri yaitu pesor

Sedangkan versi yang lain menurut Dinas Koperasi UMKM Kota Bogor ini dengan Bapak Uci menceritakan bahwa asal mulanya Kota Bogor memiliki banyak pengrajin pembuat ketupat yang menggunakan daun kelapa muda. Kemudian tersebar keberadaan pohon daun patat sebagai pengganti untuk pembungkus lontong. Penyebaran produksi ketupat atau lontong yang menggunakan daun patat ini berada di Bogor bagian utara, karena bahan baku pembuatan doclang khususnya pembuatan lontongnya yang menggunakan daun patat tersebut sangat banyak yang berada di daerah Tanah Baru dan Cimapar sebagai pusat pembuatan lontong yang menggunakan daun patat.

Doclang sendiri berasal turun temurun yang sudah mandarah daging di Kota Bogor dari para pengrajin pembuat lontong yang menggunakan daun patat dengan menambahkan bahan-bahan makanan lainnya, seperti tahu goreng, kentang goreng, telor rebus dan bumbu kacang yang disesuikan dengan cita rasa masyarakat Bogor. Penjualan yang dahulu di pikul berkeliling di setiap daerah Kota Bogor

\subsubsection{Keberadaan Doclang Dalam Masyarakat Bogor Zaman Sekarang}

Pertama kali doclang di pikul, pada tahun70an. Doclang ini milik Bapak Jumawi yang berada di daerah Jembatan Merah, namun sekarang dikenal dengan nama Umi Icoh yang dikenal sebagai istri dari Bapak Jumawi. Doclang ini pertama kali di kenal oleh anak-anak sekolah dari SMA 02 yang terletak di Jalan Perintis Kemerdekaan, mulai dari mulut ke mulut tersebar keberadaan Doclang Umi Icoh ini. Akan tetapi dari hasil penelitian dilapangan ini, Doclang Umi Icoh ini tidak menggunakan salah satu bahan yaitu telor rebus yang membuatnya berbeda dari doclang yang lainnya.

Sekitar pada tahun-80-an di daerah yang sama di Jalan Jembatan Merah, terdapat doclang yang bernama Doclang 405 Aos. Awalnya pada tahun-82, Doclang Aos ini dijalankan oleh temannya yang bejualan masih sangat tradisional yaitu dipikul dan sekitar tahun
1990 sampai tahun 2000 diambil ahli oleh Bapak Haji Aos yang berjulan di daerah Jembatan Merah yang juga tidak menggunkaan cara dipikul.

Sedangkan doclang Pak Odik merupakan doclang yang terkenal dari yang lainnya. Asal mulanya sama seperti doclang yang lainnya dengan cara di pikul berkliling didaerah Jalan Pasir Kuda. Mulai dari tahun 2000-an, Doclang Pak Odik ini digantikan oleh generasinya sendiri yaitu Bapak Ismail untuk meneruskan doclang dari ayahnya.

Ada pun perbedaan dari makanan doclang dari tiga tempat ini, sebagai berikut:

1. Doclang Jembatan Merah Umi Icoh

a. Bumbu kacang terasa gurih.

b. Warna bumbu kacang coklat terang.

c. Tekstur bumbu kacang halus.

d. Berada di pinggi jalan atau kaki lima dan menggunakan grobak.

e. Tidak menggunakan telor pada awal mula doclang dijualkan pada masyarakat.

f. Jam berjualan dari pukul 8 sampai jam 2 siang

2. Doclang Jalan Pasir Kuda Pak Odik

a. Bumbu kacang terasa manis.

b. Warna bumbu kacang sedikit gelap.

c. Tekstur bumbu kacang kasar.

d. Berada di rumah untuk berjulan dan masih menggunakan alat dipikul.

e. Pak Odik menngunakan telor seperti 405 Aos yang sudah di modifikasi sesuai perubahan zaman.

f. Jam untuk berjualan dari jam 7 pagi sampai jam 2 siang.

3. Doclang Jembatan Merah 405 Aos

a. Bumbu kacang terasa gurih.

b. Warna bumbu kacang coklat terang.

c. Tekstur bumbu kacang halus.

d. Berada di pinggi jalan atau kaki lima dan menggunakan grobak.

e. Menggunakan telor yang sudah dimodifikasi sesuai perubahan zaman.

f. Jam berjualan dari pukul 8 sampai jam 2 siang.

g. Juga ada pada sore kemalam hari dari jam 6 sore sampai sekitar pukul 9 malam.

\subsubsection{Potensi Keberadaan Doclang di Bogor}

Hasil dari survei dan wawancara menunjukkan bahwa hanya sedikit yang mengetahui keberadaan doclang sebagai makanan tradisional Khas Bogor. Doclang menyerupai ketupat sayur atau lebih miripnya menyerupai ketoprak yang memiliki bumbu kacang yang sebagai pelengkapnya. Akan tetapi, doclang memiliki keunikan tersendiri yaitu dari sisi lontongnya yang dibuat dan dibungkus berbeda dari lontong pada umumnya yang ada. 
Doclang sendiri adalah Bumbu Ledog Nganggo Kacang yang didapat dari hasil wawancara oleh pedang doclang di Jalan Jembatan Merah atau veteran, Doclang 405 Aos, yang memiliki arti bumbu kental dari kacang.

\subsubsection{Pandangan Masyarakat Dan Keunikan Doclang}

Menurut pandangan masyarakat doclang adalah makanan tradisional khas Bogor yang telah ada sejak dulu dan diwariskan secara turun-terumun. Sedangkan keunikan yang dimiliki oleh doclang adalah berasal dari lontongnya sendiri yang disebut pesor oleh orang Sunda. Dimana pembuatan pesor atau lontong ini membutuhkan waktu yang cukup lama dan dengan menggunakan pembungkus dari daun patat. Kelebihan yang dimiliki daun patat sediri menurut Bapak Ucit dari Dinas Koperasi UMKM Kota Bogor adalah daun ini tidak mudah rusak seperti daun pisang dan memiliki aroma khas yang hanya dimiliki daun patat.

Tabel 1: Daerah Domisili Responden

\begin{tabular}{|c|c|c|}
\hline $\begin{array}{c}\text { Daerah } \\
\text { Domisili Bogor }\end{array}$ & Jumlah & $(\%)$ \\
\hline Ya & 56 & $91,8 \%$ \\
\hline Tidak & 5 & $8,2 \%$ \\
\hline
\end{tabular}

Pengolahan data ini berpusat langsung pada daerah yang diteliti yaitu Kota Bogor, sebanyak $91,8 \%$ atau 56 orang dan yang tidak berdomisili di Kota Bogor sebanyak 8,2\% atau 5 orang. Data ini mayoritas berdomisili di Bogor.

Table 2: Mengetahui Makanan Tradisional Doclang

\begin{tabular}{|c|c|c|}
\hline $\begin{array}{c}\text { Mengetahui Makanan } \\
\text { Tradisional Doclang }\end{array}$ & Jumlah & (\%) \\
\hline Mengetahui & 41 & $67,2 \%$ \\
\hline Tidak Mengetahui & 20 & $32,8 \%$ \\
\hline
\end{tabular}

Berdasarkan tabel 2, dapat diketahui bahwa reponden yang menjawab mengetahui makanan doclang sebanyak $67,2 \%$ atau 41 orang dan yang menjawab tidak megetahui sebanyak $32,8 \%$ atau 20 orang. Dapat dilihat dari data diatas, ternyata responden walaupun ada yang tidak mengetahui makanan tradisional doclang khas daerahnya mungkin disebabkan oleh beberapa faktor karena bukan tinggal di daerah Bogor atau tidak mengetahui adanya makanan tersebut, akan tetapi banyak yang menjawab mengetahui makanan doclang dengan berdomisili di daerah asal doclang tersebut. Dari $67,2 \%$ sebanyak 9 responden ada yang mengetahui doclang makanan akan tetapi responden tidak mengkonsumsi doclang khas Bogor ini.

Tabel 3: Pernah mengkonsumsi Doclang

\begin{tabular}{|c|c|c|}
\hline $\begin{array}{c}\text { Mengetahui } \\
\text { Doclang }\end{array}$ & Jumlah & $(\%)$ \\
\hline
\end{tabular}

\begin{tabular}{|c|c|c|}
\hline Pernah & 33 & $54,1 \%$ \\
\hline Tidak Pernah & 28 & $45,9 \%$ \\
\hline
\end{tabular}

Berdasarkan tabel 3, diketahui bahwa reponden yang menjawab pernah mencicipi atau mengkonsumsi makanan tradisional doclang Khas Bogor sebanyak $54,1 \%$ atau 33 orang dan yang menjawab tidak pernah mengkonsumsi makanan tradisional doclang Khas Bogor sebanyak 45,9\% atau 28 orang. Dapat disimpulkan bahwa data diatas banyak yang mengkonsumsi doclang sebagai makanan tradisional akan tetapi dari data yang peneliti dapatkan bahwa ada yang mengetahui doclang sebagai makanan tradisional Khas Bogor tetapi tidak mengkonsumsi atau mencicipi makanan doclang.

Dari data yang mengetahui makanan doclang dan yang mengkonsumsi makanan ini, peneliti mendapatkan data bahwa ada sembilan responden yang mengetahui makanan doclang dan berdomisili di Kota Bogor.

Sedangkan untuk responden yang tidak pernah mengkonsumsi makanan tradisional doclang Khas Bogor sebanyak 45,9\% atau 28 orang, disebabkan oleh beberapa alasan yang dikemukakan oleh responden, diantaranya adalah:

1. Tidak adanya penjual yang berjualan didaerah tempat tinggalnya.

2. Sulit untuk menemukan Doclang

3. Merasa kurang tertarik dilihat dari komposisinya.

4. Lebih tertarik untuk mencoba makanan dari luar negeri.

5. Tidak menyukai lontong, sehingga tidak ingin mencoba doclang.

\subsubsection{Kendala dalam Melestarikan Doclang}

Menurut Dinas Koperasi UMKM Kota Bogor oleh Bapak Uci dan Dinas Kebudayaan dan Pariwisata Kota Bogor oleh Ibu Yuni, upaya pelestarian makanan tradisional adalah cara untuk mencegah makanan tradisional agar tidak hilang dari perkembangan zaman yang terus berubah serta berkembang. Doclang merupakan makanan tradisional Khas Kota Bogor yang memiliki keunikan tersendiri.

Dalam kesadaran untuk melestarikan suatu makanan yang diberikan secara turuntemurun dari generasi ke generasi ini untuk terus dijaga keberadaannya pada suatu negara. Serta, memiliki titik yang menjadi pusat wisata kuliner khususnya doclang di Jalan Jembatan Merah atau Veteran bagi para wisatawab kuliner ingin mencicipi atau mengkonsumsi makanan doclang Khas Bogor yang selalu ada pada pinggiran Jalan Jembatan Merah, yang diungkapkan oleh Dinas Koperasi UMKM Kota Bogor oleh Bapak Uci. Adapun kendala-kendala dalam melakukan pelestarian terhadap doclang yang sebagai salah satu makanan tradisional 
Khas Bogor yang mulai pudar atau terkikis oleh perkembangan zaman adalah sebagai berikut :

1. Aspek bisnis :

a. Penjualan doclang hanya terdapat di daerah Kota Bogor.

b. Keunikan dari bahan utama doclang yaitu pembungkus lontong atau pesor terdapat di daerah Kota Bogor dan sekitarnya.

c. Terdapat bisnis makan dari luar masuk ke lingkungan generasi muda yang telah mengikuti perkembangan zaman bagi generasi muda.

d. Pembuat doclang rata-rata para pedagang kaki lima atau industri rumahan yang sudah turun-temurun keberadaannya, sehingga menyebabkan kurangnya ilmu pengetahuan dalam proses bisnis di bidang kuliner.

2. Aspek Persepsi Masyarakat, khususunya Generasi Muda:

a. Generasi muda khususnya yang tidak tinggal di Kota Bogor tidak banyak yang mengetahui keberadaan doclang

b. Lebih memilih makanan atau kuliner yang telah mengikuti perkembangan zaman sesuai dengan generasi mereka, dari pada memilih untuk mengkonsumsi makanan tradisional yang sudah ada dari dulu keberadaannya.

\subsection{Kesimpulan}

Doclang merupakan makanan tradisional Kota Bogor yang memiliki keunikan dari lontong atau pesor (sebutan untuk lontong bagi orang sunda). Doclang memiliki titik pusat untuk mencicipi atau mengkonsumsinya yaitu berada pada Jalan Jembatan Merah atau yang sering disebut oleh orang sekitar Jalan Veteran. Dari seluruh kesimpulan data yang dijelaskan diatas, sebagai berikut:

1. Asal usul Doclang ada dua versi, dimana versi pertama adalah pengaruh dari masyarakat Cina/Tionghoa dan versi kedua adalah pengaruh dari pengrajin ketupat. Karena di daerah Bogor banyak terdapat daun Patat, maka terjadi peralihan dari daun bambu dan daun kelapa yang digunakan untuk pembungkus lontongnya menjadi menggunakan daun patat.

2. Dalam pembuatan doclang yang paling unik adalah dalam pembuatan lontong atau pesor yang menggunakan daun patat asli sunda dan proses pemasakkan membutuhkan waktu yang cukup lama. Sedangkan keunikan lain adalah penggunaan kentang sehingga menjadi pembeda doclang dari ketoprak dan kupat tahu.
3. Saat ini di Kota Bogor sudah menyediakan beberapa titik untuk wisata kuliner, yaitu di Jalan Jembatan Merah atau Jalan Veteran yang dijual oleh para pedagang kaki lima.

\section{Daftar Pustaka}

[1] Adiasih, P., \& Brahmana, R. K. (2015). Persepsi terhadap Makanan Tradisional Jawa Timur: Studi Awal terhadap Mahasiswa Perguruan Tinggi Swasta di Surabaya. Kinerja ( journal of Business and Economic), 15(2), 112-125.

[2] Afn, \& Dbs. (2014, 01 30). TransBogor.co. Retrieved from TransBogor.co: http://ransbogor.co/read/427/30/1/2014/docl ang-makanan-khas-tradisional-bogor-yangtergusur-zaman

[3] Afriyani, R. (2011). Analisis Daya Saing Sektor Pariwisata Kota Bogor. Fakultas Ekonomi dan Manajemen, Ilmu Ekonomi. Bogor: IPB.

[4] Ahmadlbo. (n.d.). Indonesia Kaya. Retrieved September 25, 2018, from Indonesiakaya.com:

https://www.indonesiakaya.com/jelajahindonesia/detail/doclang-sarapan-unik-yangmengenyangkan

[5] Amelia, R., Endrinaldi, \& Edward, Z. (2014). Identifikasi dan Penentuan Kadar Boraks dalam Lontong yang Dijual di Pasar Raya Padang. Jurnal Kesehatan Andalas, 3(3), 457-459.

[6] Arifin, F. (2017). Pergulatan Identitas Kultural antara Fastfood dan Kudapan. Jurnal Penelitian Humaniora, 1-7. Retrieved from

https://doi.org/10.23917/humaniora.v18i1.36 40

[7] Badar, A. A. (2006). Karakterisasi Sifat Fisiko Kimia dan Mekanik Daun Patat Daun (Phrynium capitatum) sebagai Bahan Kemasan. Bogor: IPB.

[8] BPS. (2010). Badan Pusat Statistik Kota Bogor. Retrieved from SensusPenduduk 2010:

http://www.presidenri.go.id/index.php/su

[9] Fajri, I. (2018). Strategi Peningkatan Penjualan Makanan Tradisional Sunda Melalui Daya Tarik Produk Wisata Kuliner di The Jayakarta Bandung Suite Hotel \& Spa. Tourism and Hospitality Essentials (THE) Journal, 8(1), 45-56.

[10] Gardjito, M., Putri, R. G., \& Dewi, S. (2018). Profil Struktur, Bumbu, dan Bahan dalam Kuliner Indonesia. Yogjakarta: UGM Press.

[11] Gunawan, T. (2016). Identifikasi Wisata Kuliner Kota Bogor. Jurnal Online Mahasiswa (JOM), 1(1).

[12]Hamdi, A. S., \& Bahruddin, E. (2014). Metode Penelitian Kuantitatif: Aplikasi dalam 
Pendidikan. (A. Anas, Ed.) Yogyakarta: Deepublish.

[13] Hartanti, M., Santosa, I., \& K, A. R. (2012). Kajian Emotinal Branding dan Budaya Etnik Sunda pada Restoran Tradisional Sunda. Jurnal Komunikasi Visual \& Multimedia, 4(1), 37-46.

[14] Hoerudin, I. (2013, 11 06). Rancah Post. Retrieved from Rancah Post: https://www.rancahpost.com/2013119906/do clang-kuliner-legendaris-dan-unik-khasmasyarakat-kota-bogor/

[15]Ketaren, I. (2017). Gastronomi Upaboga Indonesia. Jakarta: Indonesian Gastronomy Association.

[16] Khatimah, H. (2018, Maret 05). AyoBogor.com. Retrieved from Kota Bogor Destinasi Favorit Wisata Kuliner: http://ayobogor.com/read/20180305/122/125 3/kota-bogor-destinasi-favorit-wisata-kuliner

[17] Maengkom, D. (2015, $11 \quad 07)$. Indogastronomi. Retrieved from Indogastronomi: https://indogastronomi.wordpress.com/2015/ 11/07/antara-gastronomi-dan-kuliner/

[18] Mulyana, B. (2012). Pengembangan Kota Bogor sebagai Destinasi Pariwisata International. Jurnal IImiah Pariwisata, 2(1), 109-222.

[19] nasional.kompas.com. (2010, 04 15). Kompas.com. Retrieved from Kompas.com: https://nasional.kompas.com/read/2010/04/1 5/18500076/Doclang.Tak.Lekang.Zaman-5

[20] Nitisuari, N., \& Wardono, P. (2014). Museum Sejarah Kuliner Traditional Indonesia. Jurnal Tingkat Sarjana Bidang Senirupa dan Desain (ITB), 1, 1-7.

[21] Nurhalimah. (2016). Tentang Makanan Khas Indonesia. Jurnal Prodi PBSI UNWIR Indramayu.

[22] Oda. (2012). Pengembangan Pusat Kuliner Nusantara Kota Bandung Sebagai Tujuan Wisata. Khasanah IImu, lii(1), 51-60.

[23] Rahmalianti, R., A, M. N., \& Riyadi, D. (2016). Pelestarian Makanan Tradisional Kejos Sebagai Sumber Karbohidrat di Desa Tarikolot Kecamatan Jatinunggal Kabupaten Sumedang Provinsi Jawa Barat.
Gastronomy Tourism UPI E-Journal, 3(1), 229-237.

[24] Setiawan, H. (2015, 06 25). Kompasiana. Retrieved from https://www.kompasiana.com/hendisetiawan /550db74c8133114322b1e77e/doclangmakanan-khas-bogor

[25] Setyawati, V. A., \& Rimawati, E. (2016). Pola Konsumsi Fast Food dan Serat sebagai Faktor Gizi Lebih pada Remaja. Unnes Journal of Public Health, 5(3), 275-284.

[26] Simantjuntak, T. N. (2015, 04 29). Sarapan Nusantara. Retrieved from Detik Food.com: https://food.detik.com/info-kuliner/d2901128/doclang-sarapan-khas-bogor-yangmulai-punah-tergerus-zaman

[27] Soegiyono. (2017). Metode Penelitian Kuantitatif,Kualitatif dan R\&D. Bandung: Alfabet.

[28] Tosida, E. T., Gunawan, I., \& Andria, F. (2015). Pemberdayaan Kelompok Penggerak Pariwisata (Kompepar) dalam Pengembangan Potensi Wisata Bogor Selatan. Jurnal Ilmiah Pengabdian kepada Masyarakat, 2(1), 110-120.

[29] Tredoria.com. (2017). Retrieved 10 10, 2018, from http://tredoria.com/kuliner/doclang/

[30]Wawo, A. H., \& Sukamto, L. A. (2011). Kajian Cara Perbanyakan dan Pertumbuhan Garut (Maranta arundinaceae L.) pada Kondisi Ketersediaan Cahaya yang Berbeda. E-jurnal BPPT, 7(2), 127-136.

[31] Yasminia, D. (2003). Perilaku Konsumen Remaja Terhadap Makanan Tradisional Sunda di Bogor. Bogor: IPB. Retrieved from http://repository.ipb.ac.id/handle/123456789/ 19443

[32] Yulianti, Y. (2015, 02 23). Bogordesain. Retrieved 10 10, 2018, from Bogordesain: https://bogordesain.com/wisata-kuliner-dibogor 